\title{
HABITAT ASSOCIATIONS AND NATURAL HISTORY OF THE TASMANIAN "SNOW SKINKS" (NIVEOSCINCUS SPP.)
}

\author{
by Jane Melville and Roy Swain
}

(with two tables and four text-figures)

\begin{abstract}
Melville, J. \& Swain, R., 1999 (31:x): Habitat associations and natural history of the Tasmanian "snow skinks" (Niveoscincusspp.). Pap. Proc. R. Soc. Tasm. 133(1): 57-64. https://doi.org/10.26749/rstpp.133.1.57 ISSN 0080-4703. Formerly School of Zoology, University of Tasmania, now Department of Biology, Washington University, Campus Box 1137, St Louis, MO 63130, USA (JM); School of Zoology, University of Tasmania, GPO Box 252-5, Hobart, Tasmania, Australia 7001 (RS).
\end{abstract}

\begin{abstract}
Niveoscincus "snow skink" is the largest genus of lizards in Tasmania, but little literature is available on the ecology of the seven species discussed here. They were examined by studying the vegetation associations and natural history of all Niveoscincus species except $N$. palfreymani. Most were found to be primarily either ground-dwelling, saxicolous or arboreal, although a few species, such as $N$. microlepidotus, showed a combination of these habits. Saxicolous and heath/rock-dwelling species were restricted to more open habitats. Ground-dwelling species, on the other hand, were widespread and found in many different habitats but not in open rocky areas. Arboreal species were found in a wide range of forest habitats from sea-level to the treeline. The species studied were found to have significantly different, although partially overlapping habitat preferences.
\end{abstract}

Key Words: alpine, habitat, lizard, Niveoscincus, Tasmania.

\section{INTRODUCTION}

\section{General}

The cool to cold temperate climate of Tasmania supports a relatively impoverished reptilian fauna (Cogger \& Heatwole 1984), which is composed of 18 lizard and three snake species. Until recently, the majority of the lizard species were placed in the genus Leiolopisma (Wilson \& Knowles 1988) but recently (Hutchinson etal. 1990) this has been recognised as polyphyletic. Hutchinson et al. (1990) revised the genus using morphological and molecular characters; one consequence of this revision was the formation of Niveoscincus (= "snow skink"). This is the largest of the ten genera of lizards known from Tasmania, with seven of the eight described species occurring on the island.

Although the taxonomy of Niveoscincus has been clarified, little published literature on any ecological aspects of the species' biology is available. The most extensive review of the ecology, biogeography and natural history of Tasmanian lizards was provided by Rawlinson (1974); this remains the only detailed examination recorded. However, this work is now outdated, as it predated the description of Niveoscincus and did not include all the species now recognised. We provide the first quantitative investigation of the vegetation associations and natural history of seven species of Niveoscincus. The work described here formed part of a larger study of Tasmanian snow skinks (Melville 1998).

\section{Current knowledge of the ecology of Niveoscincus species}

Since the review by Rawlinson (1974), three new species, Niveoscincus greeni and N. coventryi (Rawlinson 1975) and $N$. orocryptus (Hutchinson etal. 1988), have been described and $N$. microlepidotus has been redescribed (Hutchinson et al. 1989). Previously $N$. microlepidotus was included in $N$. pretiosus. $N$. microlepidotus and $N$. orocryptus, along with $N$. greeni, are the three truly alpine species found in Tasmania.
Brief descriptions of the habitat and distributions of these alpine species are available in Hutchinson et al. (1988, 1989), Hutchinson \& Schwaner (1991) and Hutchinson \& Hudson (1998). More detailed studies of the ecology and behaviour of $N$. microlepidotus have been provided by Melville \& Swain (1997a, b, 1998) and Olsson \& Shine (1998a, b). The three alpine species occur in largely disjunct populations on mountain tops above $1000 \mathrm{~m}$ in southern Tasmania $(N$. microlepidotus), western Tasmania ( $N$. orocryptus) and northeastern and central Tasmania $(N$. greeni) (Hutchinson \& Schwaner 1991, Hutchinson \& Hudson 1998). N. microlepidotus and $N$. greeni occur above the treeline and are restricted to more open areas, particularly dolerite boulder fields. $N$. orocryptus, on the other hand, is reported to be restricted to the treeline in some areas, such as Mt Eliza, but occurs above this point in other areas, such as Mt Hartz (Hutchinson et al. 1988).

The general ecology and distribution of the metallic skink, N. metallicus, are better known (Rawlinson 1974). Also, some thermoregulatory data have been incorporated into larger studies (Bennett \& John-Alder 1986), and there are a number of recent papers dealing with reproductive physiology (Swain \& Jones 1994, 1997, Jones \& Swain 1996, Jones et al. 1998). This ground-dwelling species has a wide distribution and occurs in many habitats over a broad altitudinal range, from dry sclerophyll woodlands to sub-alpine heaths. The environmental disturbance associated with development appears to have benefited this species, and it is commonly found in suburban gardens and in vegetation along roadsides.

The other ground-dwelling species considered in this paper, $N$. coventryi, has been little studied. $N$. coventryi is a cryptic lizard found in tall highland forests in Victoria, where it occurs in the thick layers of bark and leaf litter (Webb 1985). Although the species has been incorporated into larger studies of thermoregulation and general ecology (Webb 1985, Bennett \& John-Alder 1986), no detailed ecological data are available.

The remaining two species which have been investigated in this study are the arboreal snow skink $N$. pretiosus and 
the saxicolous species $N$. ocellatus. $N$. pretiosus is a small, agile skink which occurs throughout Tasmania, up to an altitude of $1000 \mathrm{~m}$ (treeline). It is found mainly on fallen branches and trunks which form breaks in the forest canopy. However, in western Tasmania it is also saxicolous in some areas (Hutchinson \& Schwaner 1991).

$N$. ocellatus is the largest species of Niveoscincus on mainland Tasmania and occurs on rocky outcrops in eastern, central and northern Tasmania. There is a very large range in body size in this species. Individuals from populations at higher altitudes (up to $1000 \mathrm{~m}$ ) are almost one-third larger than those at sea-level (E. Wapstra, pers. comm.). Little work has been published for this species, although Wapstra \& Swain (1996) examined feeding ecology, and reproductive cycles and annual profiles of reproductive steroid hormones have recently been described (Jones et al. 1997).

The remaining species of Niveoscincus is $N$. palfreymani (the Pedra Branca skink) which is the only endangered Tasmanian reptile listed as threatened. Both the Tasmania Threatened Species Protection Act 1995 and the Commonwealth Endangered Species Protection Act 1992 record it as "vulnerable". It is also the largest species of Niveoscincus, with snout-vent lengths of up to $90 \mathrm{~mm}$. This species consists of a single population living on a rocky islet (Pedra Branca) $26 \mathrm{~km}$ off the south coast of Tasmania. In 1997, the population had dropped from around 500 animals to about 200 (N. Brothers, pers comm.). Pedra Branca is a barren windswept island with no vegetation. The lizards feed on fish dropped or regurgitated by the bird colonies. Consequently, the lizard population is dependent on the wellbeing of the bird colony. Although little has been published on this species, a monitoring programme has been maintained on the bird and lizard populations of Pedra Branca since 1978. All lizards are toe-clipped, and life-history data have been collected by the Tasmanian National Parks and Wildlife Service. The only published data on this species are provided by Rounsevell et al. (1985).

\section{MATERIALS AND METHODS}

\section{Study Species}

Niveoscincus is a group of small to medium-sized lygosomine skinks, diagnosed by well-developed prefrontal shields, paired or fused frontoparietals, a distinct interparietal shield and a moveable lower eyelid with a moderate to large transparent palpebral disc (Hutchinson et al. 1989). Six species are endemic to Tasmania: $N$. greeni, $N$. microlepidotus, $N$. ocellatus, $N$. orocryptus, $N$. palfreymani and $N$. pretiosus (fig. 1). The distribution of $N$. metallicus extends from Tasmania into southern Victoria, while $N$. coventryi is restricted to southeastern Australia. Since there is some uncertainty about the taxonomic status of the $N$. orocryptus population at Mt Hartz (Hutchinson \& Schwaner 1991, Melville \& Swain 1998), the two populations of $N$. orocryptus that we examined were treated separately.

Hutchinson \& Schwaner (1991) identified three species groupings in Niveoscincus. ground-dwelling ( $N$. coventryi and $N$. metallicus), arboreal ( $N$. pretiosus and $N$. orocryptus [Mt Eliza population]) and saxicolous species ( $N$. greeni, $N$. microlepidotus, $N$. ocellatus and $N$. orocryptus Mt Hartz population). The saxicolous species can be further divided into specialists ( $N$. greeni and $N$. ocellatus) and heath/rockdwelling species $(N$. microlepidotus and $N$. orocryptus $[\mathrm{Mt}$ Hartz population]) (Melville 1998).

\section{Fieldwork}

Habitat associations were recorded at 11 field sites chosen to cover a broad range of habitat types and altitudes (table 1). Most species were studied at two field sites. The data were recorded by starting at a randomly determined location at each field site and moving back and forth across the site to ensure coverage of the entire range of microhabitats available. Measures of canopy heights and undergrowth vegetation

TABLE 1

Location of field sites with a brief vegetation description of the microhabitats occupied by each study species

\begin{tabular}{|c|c|c|c|c|c|c|}
\hline Species & Site & $\mathrm{n}$ & Basking surface & Undergrowth type & Canopy type & Substrate type \\
\hline$N$. coventryi & Mt St Leonards & 41 & ground/litter & tall shrubs/trees $(>2 \mathrm{~m})$ & tall eucalypts $(>30 \mathrm{~m})$ & soil/deep litter \\
\hline$N$. greeni & Ben Lomond & 55 & boulder & usually absent & absent & dolerice boulders \\
\hline N. greeni & Mt Pelion East & 66 & boulder & usually absent & absent & dolerite boulders \\
\hline N. metallicus & Orford & 71 & $\begin{array}{l}\text { ground/litter/ } \\
\text { rock }\end{array}$ & small shrubs $(<1 \mathrm{~m})$ & eucalypts $(<15 \mathrm{~m})$ & soil/rocks/litter \\
\hline N. metallicus & Clarence Lagoon & 60 & $\begin{array}{l}\text { ground/litter/ } \\
\text { rock }\end{array}$ & small-tall shrubs $(0-2 \mathrm{~m})$ & eucalypts $(15-40 \mathrm{~m})$ & soil/rocks/litter \\
\hline N. microlepidotus & Mt Hartz & 55 & heath/boulder & alpine heath $(<0.8 \mathrm{~m})$ & absent & peat/dolerite boulders \\
\hline N. microlepidotus & Mt Wellington & 49 & heath/boulder & alpine heath $(<0.8 \mathrm{~m})$ & absent & peat/dolerite boulders \\
\hline N. ocellatus & Central Plateau & 61 & boulder & sub-alpine heaths $(<1 \mathrm{~m})$ & absent & sand/dolerite boulders \\
\hline N. ocellatus & Orford & 37 & rock/boulder & low shrubs $(<0.8 \mathrm{~m})$ & eucalypts $(<15 \mathrm{~m})$ & dolerite rocks/litter \\
\hline N. orocryptus & Mt Eliza & 66 & $\begin{array}{l}\text { heath/boulder/ } \\
\text { ground }\end{array}$ & alpine heath $(<1.5 \mathrm{~m})$ & eucalypts $(<15 \mathrm{~m})$ & peat/dolerite boulders \\
\hline N. orocryptus & Mt Hartz & 75 & heath/boulder & alpine heath $(<0.8 \mathrm{~m})$ & absent & peat/dolerite boulders \\
\hline$N$. pretiosus & Clarence Lagoon & 56 & $\log /$ rock & small-tall shrubs $(0-2 \mathrm{~m})$ & eucalypts $(15-40 \mathrm{~m})$ & soil/rocks/litter \\
\hline N.pretiosus & Pirates Bay & 49 & $\log$ & tall shrubs/trees $(>1.5 \mathrm{~m})$ & eucalypts $(20-50 \mathrm{~m})$ & soil//itter \\
\hline
\end{tabular}



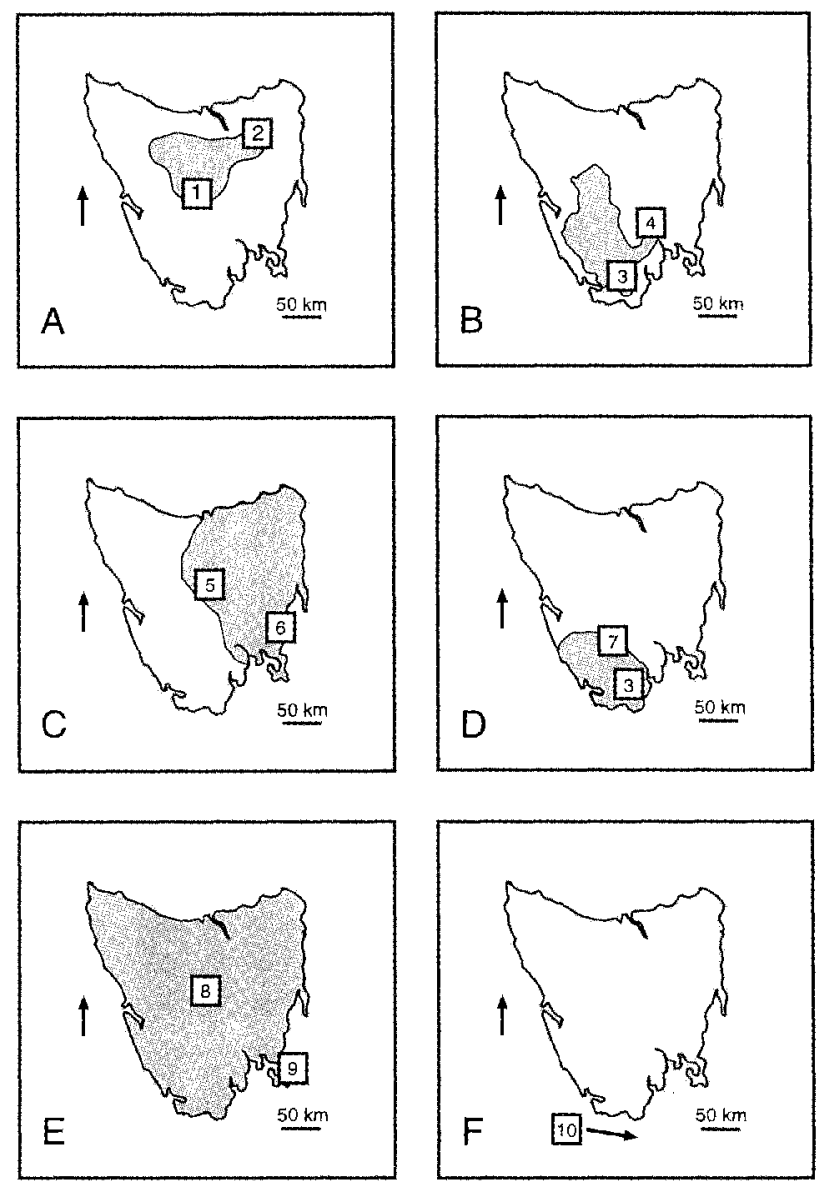

cover were based on visual estimates. Prior to fieldwork, measurements of a range of these three factors were conducted to allow more accurate visual estimations to be made. The number of lizards observed for this study varied between field sites, and the total number of specimens for which vegetation association was recorded at each site ranged from 49 to 65 . Whether or not a lizard was captured, ten structural characteristics of the vegetation were recorded: (1) canopy type: eucalypt, rainforest or other; (2) visual estimate of percent canopy cover in a $3 \mathrm{~m}^{2}$ radius surrounding lizard; (3) visual estimate of canopy height in metres; (4) basking surface - rock, litter, ground, log, branch or tree trunk; (5) undergrowth vegetation type - trees $(>2 \mathrm{~m})$, shrubs (1-2 $\mathrm{m})$, shrubs $(<1 \mathrm{~m})$, ground cover, grass or none; (6) distance to the nearest vegetation in centimetres; (7) visual estimate of percentage undergrowth vegetation cover in a $3 \mathrm{~m}^{2}$ radius surrounding lizard; (8) average measure of undergrowth vegetation height in metres; (9) substrate type - litter, rock, gravel, soil, and combinations of these; and (10) visual estimation of substrate wetness, measured on a scale of $1-6(1=$ dry substrate, $6=$ surface water visible $)$.

The data collected from these observations were analysed using ANOVA to identify differences between species and species groups. In no cases were assumptions of normality violated, and analyses were carried out, therefore, without data transformation. Fishers LSD post hoc tests were used to identify the comparisons that accounted for any significant differences.
FIG. 1 - Location of field sites and approximate distributions (shaded) on the Tasmanian mainland of the six endemic species of Niveoscincus. Numbers identify field sites (see table 1); shading indicates distribution.

$A-\mathrm{N}$. greeni; $B-\mathrm{N}$. microlepidotus; $C-\mathrm{N}$. ocellatus; $D$ $-\mathrm{N}$. orocryptus; $E-\mathrm{N}$. pretiosus and $N$. metallicus; $F-\mathrm{N}$. palfreymani. Niveoscincus palfreymani is restricted to a small islet off the south coast of Tasmania (Field Site 10). The distribution of $\mathrm{N}$. coventryi is not provided: $\mathrm{N}$. coventryi does not occur in Tasmania, while N. metallicus extends into southeastern Australia.

Species (site name) collected at each site: $1-\mathrm{N}$. greeni (Mt Pelion East); 2 - N. greeni (Ben Lomond); 3 - N. microlepidotus, N. orocryptus (Mt Hartz); $4-\mathrm{N}$. microlepidotus (Mt Wellington); $5-\mathrm{N}$. ocellatus (Central Plateau); $6-$ N. ocellatus, N. metallicus (Orford); 7-N. orocryptus (Mt Eliza); 8 - N. metallicus, N. pretiosus (Clarence Lagoon); $9-\mathrm{N}$. pretiosus (Pirates Bay); $10-\mathrm{N}$. palfreymani (Pedra Branca).

\section{RESULTS}

The seven species we studied were associated with a range of different vegetation types (table 2 ). The ground-dwelling species ( $N$. coventryi and $N$. metallicus) were recorded in grasslands, dry sclerophyll, wet sclerophyll and mixed forests. The saxicolous species were observed in more open areas: $N$. greeni exclusively in alpine boulder fields and $N$. ocellatus in dry sclerophyll woodlands and sub-alpine heaths. The heath/rock-dwelling species ( $N$. microlepidotus and $N$. orocryptus [Mt Hartz population]) were recorded in all habitat types which occur above the treeline. The arboreal species ( $N$.pretiosus and $N$. orocryptus [Mt Eliza population]) were observed in a range of forest habitats from wet sclerophyll to alpine woodlands.

The distance to the nearest undergrowth vegetation varied both interspecifically $\left(\mathrm{F}_{8,755}=86.18, \mathrm{P}<0.001\right)$ and intraspecifically (fig. 2). The two populations of $N$. microlepidotus varied significantly $\left(\mathrm{F}_{1.102}=20.52, \mathrm{P}<0.001\right)$, which may be a result of very different levels of vegetation cover at the two field sites. Mt Hartz has more extensive areas of alpine heathlands than Mt Wellington. $N$. greeni and $N$. ocellatus showed no intraspecific differences in distance to the nearest vegetation, yet there were significant differences between these species $(\mathrm{P}<0.001)$. Overall, the ground-dwelling species were found significantly closer to vegetation than saxicolous $(\mathrm{P}<0.001)$, heath/rock-dwelling $(\mathrm{P}=0.034)$ and arboreal species $(\mathrm{P}<0.001)$. 
TABLE 2

Range of vegetation types recorded for each species at each field site

\begin{tabular}{|c|c|c|}
\hline Species & Field sites & Habitat description* \\
\hline N. coventryi & Mt St Leonards & Wet sclerophyll forest \\
\hline \multirow[t]{2}{*}{$N \cdot$ greeni } & Ben Lomond & Alpine boulder field \\
\hline & Mt Pelion East & Alpine boulder field \\
\hline \multirow[t]{2}{*}{ N. metallicus } & Clarence Lagoon & Wet/dry sclerophyll forest \\
\hline & Orford & Dry sclerophyll woodland \\
\hline \multirow[t]{2}{*}{ N. microlepidotus } & Mt Hartz & $\begin{array}{l}\text { Alpine boulder field \& } \\
\text { alpine heathland }\end{array}$ \\
\hline & Mt Wellington & $\begin{array}{l}\text { Alpine boulder field \& } \\
\text { alpine heathland }\end{array}$ \\
\hline \multirow[t]{2}{*}{ N. ocellatus } & Central Plateau & $\begin{array}{l}\text { Boulder fields in wet } \\
\text { heathlands }\end{array}$ \\
\hline & Orford & $\begin{array}{l}\text { Rocky slopes in } \\
\text { sclerophyll woodlands }\end{array}$ \\
\hline \multirow[t]{2}{*}{$N$. orocryptus } & Mt Eliza & $\begin{array}{l}\text { Sub-alpine sclerophyll } \\
\text { woodland }\end{array}$ \\
\hline & Mt Hartz & $\begin{array}{l}\text { Alpine boulder field \& } \\
\text { alpine heathland }\end{array}$ \\
\hline \multirow[t]{2}{*}{$N \cdot$ pretiosus } & Clarence Lagoon & $\begin{array}{l}\text { Wet sclerophyll forest \& } \\
\text { mixed forest }\end{array}$ \\
\hline & Pirates Bay & Wet sclerophyll forest \\
\hline
\end{tabular}

* Sclerophyll forest - open canopy which is over $15 \mathrm{~m}$ in height and dominated by Eucalyptus spp. Dry sclerophyll has a low sparse understorey, usually under $1.2 \mathrm{~m}$ in height. Wet sclerophyll has a tall dense understorey, at times up to $5 \mathrm{~m}$ in height.

Boulder field - large dolorite boulders ranging in size from $0.2 \mathrm{~m}$ up to several metres in diameter. Little or no vegetation is present.

Sclerophyll woodland - sparse or patchy canopy under $15 \mathrm{~m}$ in height and dominated by Eucalyptus spp. Understorey usually sparse and below $1.2 \mathrm{~m}$ in height.

Heathland - canopy absent, vegetation dense and low.

Mixed forest - tall dense canopy dominated by Eucalyptusspp. with a subcanopy and tall understorey dominated by temperate rainforest species, such as Nothofagus cunninghamii.

The heath/rock-dwelling and saxicolous species were observed in areas with significantly lower undergrowth height than the arboreal and ground-dwelling species $\left(\mathrm{F}_{3,760}=104.36, \mathrm{P}<0.001\right)$ (fig. 2$)$. This result may have been influenced by the fact that the majority of the heath/ rock-dwelling and saxicolous species occupy alpine habitats, and these tend to have lower vegetation structure. However, the height of the vegetation surrounding $N$. ocellatus did not differ significantly from other saxicolous $(P=0.089)$ and heath/rock-dwelling species ( $\mathrm{P}=0.055)$, even though this is a species with many lowland populations. N. ocellatus and $N$. metallicus did differ significantly in the height of the surrounding undergrowth vegetation at the Orford field site $(\mathrm{P}<0.001)$. The vegetation height associated with ground-dwelling lizards was highly variable and reflected the wide range of vegetation types occupied by these species; this encompassed the spectrum from grasslands to tall wet sclerophyll forest (table 2).
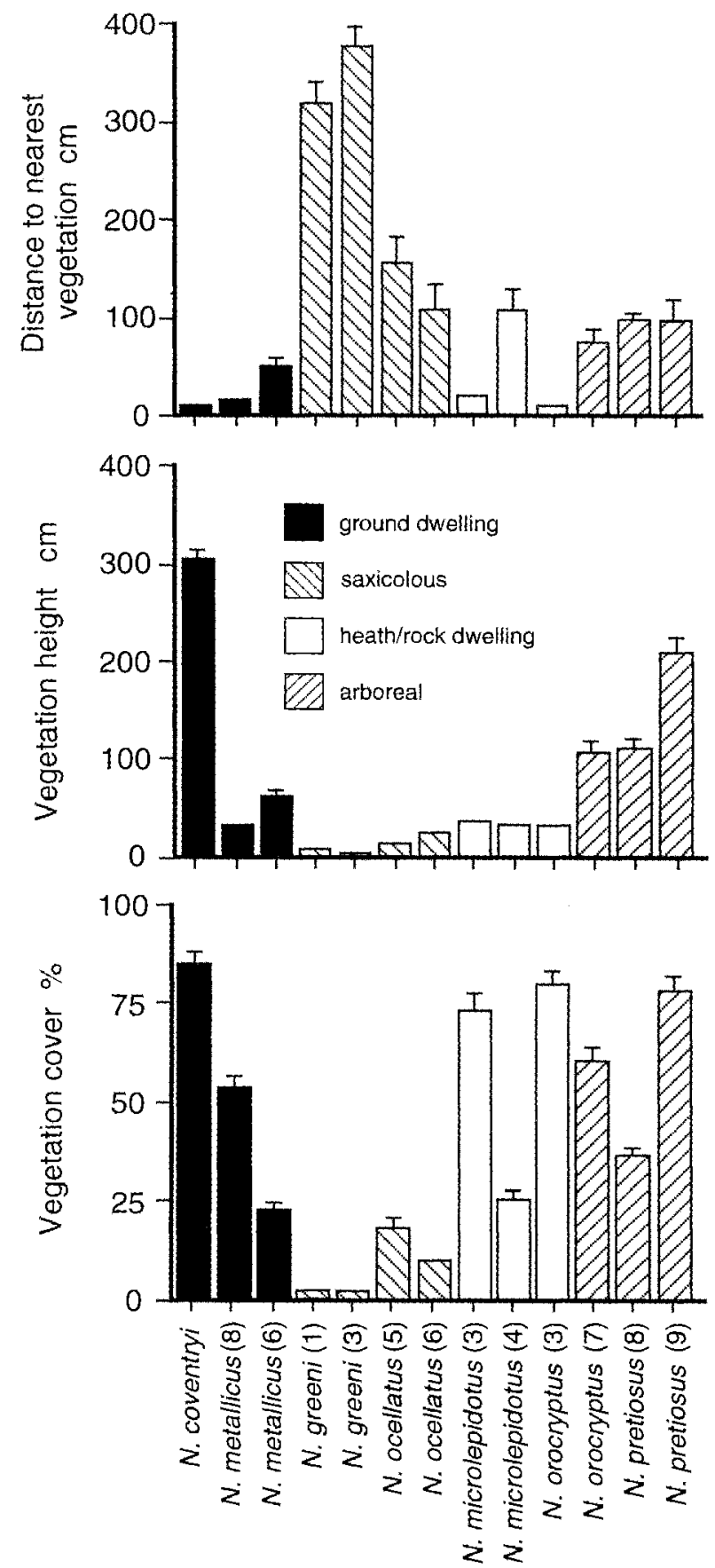

FIG. 2 - Habitat vegetation characteristics associated with each species. Values are means \pm 1 standard error. Numbers in parentheses are site locations identified in figure 1.

The percentage of undergrowth vegetation cover was variable between sites and species (fig. 2). There was no significant difference between vegetation cover recorded for the ground-dwelling, arboreal and heath/rock dwelling species. However, the saxicolous species were recorded in areas with significantly less vegetation cover than the other species $(\mathrm{P}<0.001)$. There were also significant differences between species at the same field sites. $N$. ocellatus was recorded from locations with significantly less vegetation cover than $N$. metallicus at the Orford site $(\mathrm{P}<0.001) . N$. metallicus also differed significantly from $N$. pretiosus at 
Clarence Lagoon $(\mathrm{P}<0.001)$; it used the ground and rocks, while $N$. pretiosus used the large number of fallen tree trunks and branches available.

Perch height (height above ground when sighted) was significantly higher in both saxicolous and arboreal species than in the other species groups $(\mathrm{P}<0.001$ in all post hoc comparisons) (fig. 3), while the heath/rock-dwelling species differed significantly from the ground-dwelling species $(\mathrm{P}=0.021)$. The perch height of $N$. ocellatus and $N$. metallicus varied significantly at the Orford site $(\mathrm{P}<0.001)$ and $N$. metallicus and $N$. pretiosus differed significantly in perch height at Clarence Lagoon $(\mathrm{P}<0.001)$. There was no signifcant difference in the perch height of saxicolous and arboreal species.

There were highly significant differences in canopy height $\left(\mathrm{F}_{3,760}=305.41, \mathrm{P}<0.001\right)$ and cover $\left(\mathrm{F}_{3,760}=287.21\right.$, $\mathrm{P}<0.001$ ) recorded for the groups of species (fig. 3 ). This was mainly due to the lack of canopy in any of the field sites where the saxicolous and heath/rock dwelling species occur, except for $N$. ocellatus at Orford. The alpine species were not observed when a canopy was present, with the exception of $N$. orocryptus at Mt Eliza. $N$. ocellatus occupied areas at the Orford site which had significantly less canopy cover $(\mathrm{P}<0.001)$ and a lower canopy height $(\mathrm{P}<0.001)$ than those used by $N$. metallicus. $N$. coventryi was observed to occupy locations with significantly more canopy cover and a taller canopy than all other species $(\mathrm{P}<0.001$ for all comparisons).

\section{DISCUSSION}

\section{Habitat Associations}

\section{Niveoscincus coventryi}

This species has previously been studied in the central highlands of Victoria and described as a cryptic species associated with deep layers of litter and vegetation (Rawlinson 1975, Greer 1982, Brown \& Nelson 1993). Webb (1985), in a study of microhabitat use in some southeastern Australian skinks, found that $N$. coventryi spent $92 \%$ of their time in the litter. This is very similar to the findings of this study, where the lizards occupied the deep litter layers on the ground. $N$. coventryioccupied the most closed microhabitat of all Niveoscincus species. It is very cryptic, basking in small patches of dappled sunlight.

\section{Niveoscincus greeni}

This is the first study to quantify the microhabitat of $N$. greeni, which has previously been described as a saxicolous species (Rawlinson 1975, Greer 1982, Hutchinson \& Schwaner 1991), occupying a similar type of microhabitat to $N$. microlepidotus. Our data support the conclusion that $N$. greeni is saxicolous, as it was found only in open boulder fields, even when other microhabitats were only metres away. It is much more specialised in its microhabitat occupation than $N$. microlepidotus. Over the three years of our study, $N$. green $i$ was never seen outside the open boulder fields. At the Mt Pelion East field site, $N$. greeni and $N$. microlepidotus occur in syntopy but occupy very different microhabitats. N. greeni occupies small patches of boulders, while $N$. microlepidotus is found only in heath and peat areas. Hutchinson \& Hudson (1998) suggest that these two species may occur sympatrically through most of the Central Plateau peaks, with a consistent separation in habitat usage.
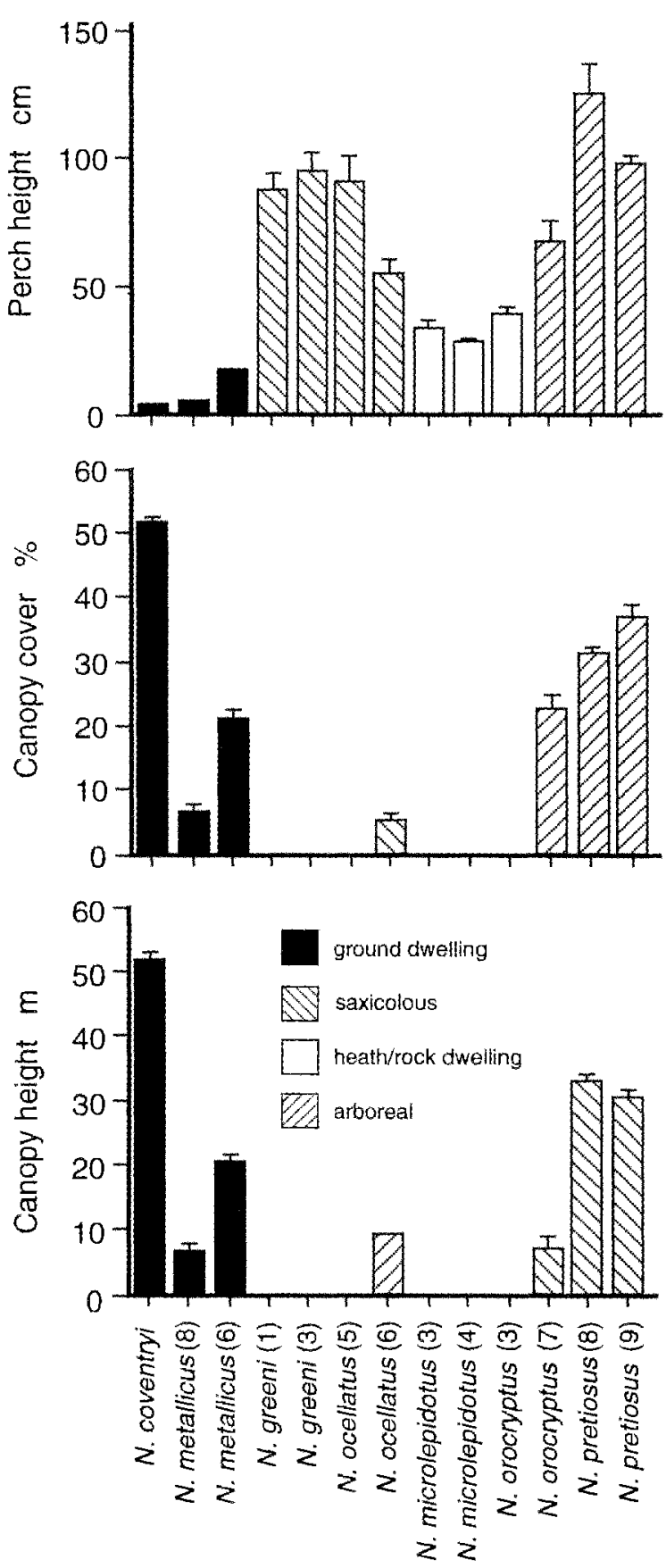

FIG. 3 - Perch height and canopy characteristics associated with each species. Values are means \pm 1 standard error. Numbers in parentheses are site locations identified in figure 1.

\section{Niveoscincus metallicus}

All previous reports have described N. metallicus as a grounddwelling and relatively cryptic species, found in a wide range of habitats (Rawlinson 1974, Hutchinson \& Schwaner 1991, Melville \& Swain 1997a, b). Our analysis supports this description; this species occupies shaded microhabitats with medium to dense vegetation cover, soil and thick litter.

$N$. metallicus appears to be restricted to a more closed microhabitat at the higher altitude Clarence Lagoon site (900 $\mathrm{m}$ a.s.1.) than at Otford $(50 \mathrm{~m}$ a.s.l.). There was a dense canopy with more undergrowth, and the lizards at this site tended to bask on rocks to a greater extent than the 
lizards at Orford, despite the fact that there were greater numbers of logs available for basking at Clarence Lagoon. At the Orford field site, $N$. metallicus occupies an open microhabitat but is more closely associated with litter layers and ground-cover vegetation. These observations are consistent with the conclusions of Melville \& Swain (1997a), who found that N. metallicus occupied a fairly closed microhabitat at a high-altitude site on Mt Wellington (1000 $\mathrm{m}$ a.s.l.) in southern Tasmania.

\section{Niveoscincus microlepidotus}

The results obtained from our analysis of microhabitat occupation by $N$. microlepidotus support the existing descriptions of habitat preferences for this species. Hutchinson et al. (1989) described N. microlepidotus as an alpine species that occurs in large numbers in dolerite boulder fields above $1000 \mathrm{~m}$ in southern Tasmania. Our study confirms that $N$. microlepidotus has a preference for the open boulder fields, on which it basks, in agreement with our earlier study of this species on Mt Wellington (Melville \& Swain 1997a). However, we find that $N$. microlepidotus also uses other microhabitats: alpine heaths and sub-alpine woodlands.

We have identified a large difference in microhabitat occupation at Mt Wellington and Mt Hartz. At Mt Hartz, $N$. microlepidotus occupied the heathland, basking on branches, the top of heath plants, the ground or cushion plants, as well as the few available rocks. These observations suggest that $N$. microlepidotus is an effective alpine generalist. Open boulder fields may represent the preferred microhabitat, since the lizards are most abundant in this habitat (Melville \& Swain 1997a); nevertheless, unlike $N$. greeni, they are also able to exploit suboptimal microhabitats such as the heathlands. Where $N$. microlepidotus and $N$ greeni co-occur, the latter species is the sole occupant of the boulder habitat, suggesting that competitive exclusion may exist, although separation may also result from differences in environmental tolerances or thermoregulatory requirements.

\section{Niveoscincus ocellatus}

Our study confirms that $N$. ocellatus is a saxicolous species, occurring in open, rocky outcrops. It is the only species of Niveoscincus that both is wholly saxicolous and occurs at low altitudes. There was no significant difference in microhabitat occupation between the two field sites, despite very large differences in macrohabitat.

The Orford field site is lowland woodland with shrubby undergrowth, extensive areas of litter, bare ground and outcrops of rock. Thus, there are many different microhabitats that $N$. ocellatus could occupy. Despite this, the lizards use only a restricted microhabitat similar to that recorded from the open wet heathlands of the Central Plateau.

\section{Niveoscincus orocryptus}

Mt Eliza is the type locality for $N$. orocryptus, which was only recognised in 1988 by Hutchinson et al. (1988), who described it as a semi-arboreal species, which spends much of its time moving through the shrubs and rocky outcrops in sub-alpine areas. They also observed it climbing small, stunted eucalypt trees. This description agrees closely with our observations of this species at this site. Lizards were observed to bask on both shrubs and rocks and were often seen basking at heights above $1 \mathrm{~m}$. We never found $N$. orocryptus above the treeline and it appears to be restricted to the sub-alpine woodland, which occurs in a small band at about $1000 \mathrm{~m}$ at Mt Eliza.

However, $N$. orocryptus at the Mt Hartz field site occupy a significantly different microhabitat. Moreover, at $\mathrm{Mt}$ Hartz this microhabitat was indistinguishable from that used by N. microlepidotus at that site. The extensive overlap in microhabitat use by these two species is further confused by their similarity in appearance; identification had to be confirmed by capture. Hutchinson \& Schwaner (1991) reported that, in the far southwest of Tasmania, $N$. microlepidotus and $N$. orocryptus are morphologically indistinguishable, and there are not even strong genetic differences between them. Consequently, possible hybridisation between $N$. orocryptus and $N$. microlepidotus at $\mathrm{Mt}$ Hartz may play an important role in the significant difference in microhabitat occupation between the two populations of $N$. orocryptus.

\section{Niveoscincus pretiosus}

This is a species which occupies forested areas, especially thickly vegetated habitats. $N$. pretiosuswas observed to move around on large fallen trees which create breaks in the canopy, providing large patches of sunlight for basking.

The two field sites used in this study are very different, yet the lizards occupy very similar microhabitats. The Pirates Bay field site is a highly disturbed wet sclerophyll forest. The land has been cleared and the current vegetation is regrowth. Lizards were recorded in greatest numbers moving around on large trees that had been bulldozed into piles in the forest. There were very few rocks available, and the lizards used logs exclusively as basking sites. The Clarence Lagoon field site, on the other hand, has large outcrops of rocks but $N$. pretiosus were rarely recorded using them as basking sites. The lizards at Clarence Lagoon consistently occupy the extensive areas of fallen trees.

$N$. pretiosus has been described previously as a scansorial species adapted to living on fallen logs, trees or rock outcrops (Hutchinson et al. 1989). We found that it occurs in a range of habitats where there are trees or where rocks outcrop, using the elevated surfaces of fallen logs, the trunks and lower branches of trees and, less frequently, rocks for basking sites. On some of the small offshore islands inhabited by $N$. pretiosus, trees are almost or totally absent, and in these areas it is saxicolous (Hutchinson et al. 1989). The current study indicates that, in central and southeastern mainland Tasmania, $N$. pretiosus is a forestdwelling, arboreal species.

\section{CONCLUSIONS}

In terms of general biology Niveoscincus forms a fairly homogenous genus of closely related species. All species have diurnal activity patterns, and are active foragers (having a predominantly arthropod-based diet), shuttling heliotherms. All of the species thermoregulate behaviourally by restricting activity times, altering body postures and shuttling between sun and shade. They have different, although partially overlapping geographic distributions and habitat preferences. Despite these similarities, Niveoscincus has radiated significantly in ecology and behaviour. Most of the species are either primarily terrestrial, saxicolous or arboreal. A few species, such as $N$. microlepidotus, show a combination of saxicolous, ground-dwelling and arboreal behaviours.

The ecological range of each species is summarised in 
figure 4. The saxicolous and heath/rock-dwelling species are restricted to more open habitats above the treeline, with the exception of $N$. ocellatus, which occurs in open rocky situations in lowland areas of Tasmania. The grounddwelling species, on the other hand, are widespread and found in many different habitats. However, they do not occur in open rocky areas or above the treeline. The arboreal species are found in a wide range of forest habitats from sea-level to the treeline. Recently completed molecular work (Melville, pers. obs.) indicates that there are a number of adaptive clades within Niveoscincus. The ground-dwelling species are ancestral, with subsequent evolution of the arboreal species; the most recently derived species are the heath/rock-dwelling and saxicolous species respectively. Thus, Niveoscincus appears to represent an adaptive radiation of ecological and behavioural characteristics.

\section{ACKNOWLEDGEMENTS}

We thank the Hobart City Council for allowing work in the Mount Wellington Reserve and the Department of Environment and Land Management for permission to study in various Tasmanian National Parks. We are also grateful to the Victorian Department of Conservation and Natural Resources for permission to collect and observe $N$. coventryi. We appreciate comments made by $\mathrm{R}$. Glor on early drafts of this paper.

\section{REFERENCES}

BEnNeTt, A.F. \& John-Alder, H., 1986: Thermal relations of some Australian skinks (Sauria: Scincidae). Copeia 1986: $57-64$.

BRown, G.W. \& NeLson, J.L., 1993: Influence of successional stage of Eucalyptus regnans (mountain ash) on habitat use by reptiles in the Central Highlands, Victoria. Aust. J. Ecol. 18: 405-417.

Cogger, H. \& Heatwole, H., 1984: The Australian Reptiles: origins, biogeography, distribution patterns and island evolution. In Archer, M. \& Clayton, G. (Eds): VERTEBRATE ZOOGEOGRAPHY AND EVOLUTION IN AUSTRALASIA. Hesperian Press, Carlisle, Western Australia: 343-360.

GREER, A.E., 1982: A new species of Leiolopisma (Lacertilia: Scincidae) from Western Australia, with notes on the biology and relationships of other Australian species. Rec. Aust. Mus. 34: 549-573.

Hutchinson, M.N. \& Hudson, S., 1998:. Reptiles. In Driessen, M.M., Comfort, M.D., Jackson, J., JBalmer, J., Richardson, A.M.M. \& McQuillan, P.B. (Eds): WILDERNESS ECOSYSTEM BASELINE STUDIES (WEBS): PELION PLAINS-MT OSSA. Tasm. Parks and Wildl. Serv. Wildl. Rep. 98/2: 183-186.

Hutchinson, M.N. \& SCHWANER, T.D., 1991: Generic relationships among the Tasmanian scincid lizards of the genus Niveoscincus. J. Herpetol. 25: 49-58.

Hutchinson, M.N., Schwaner, T.D. \& Medlock, K., 1988: A new species of scincid lizard (Lygosominae: Leiolopisma) from the highlands of Tasmania. Proc. R. Soc. Vict. 100: $67-73$.

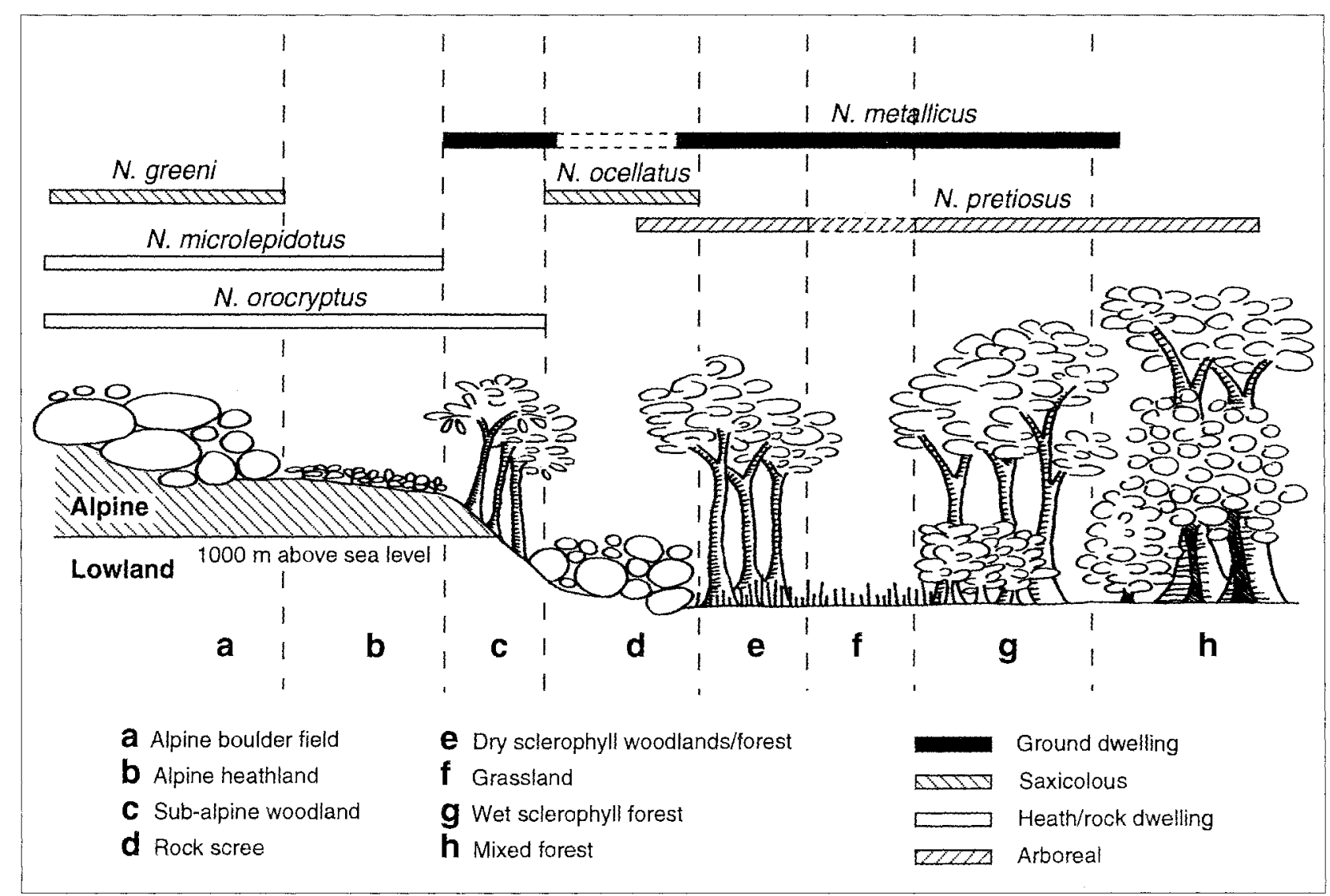

FIG. 4 - Summary of habitat associations for all Tasmanian species studied. 
Hutchinson, M.N., Robertson, P. \& Rawlinson, P.A., 1989 : Redescription and ecology of the endemic Tasmanian scincid lizards Leiolopisma microlepidotum and $L$. pretiosum. Pap. Proc. R. Soc. Tasm.123: 257-273.

Hutchinson, M.N., Donnellan, S.C., Baverstock, P.R., Kreig, M., Simms, S. \& Burgin, S., 1990: Immunological relationships and generic revision of the Australian lizards assigned to the genus Leiolopisma (Scincidae: Lygosominae). Aust. J. Zool. 38: 535-554.

JONES, S. \& SWAIN, R., 1996:. Annual reproductive cycle and annual cycles of reproductive hormones in plasma of female Niveoscincus metallicus (Scincidae) from Tasmania. J. Herpetol. 30: 140-146.

Jones, S., WaPSTRA, E. \& SWAin, R., 1997: Asynchronous male and female gonadal cycles and plasma steroid concentrations in a viviparous lizard, Niveoscincus ocellatus (Scincidae), from Tasmania. Gen. Comp. Endocrinol. 108: 271-281.

Jones, S.M, BenNetT, E.J. \& SWADLING, K.M., 1998: Lipids in yolks and neonates of the viviparous lizard Niveoscincus metallicus. Comp. Biochem. Physiol. 121 B: 465-470.

Melville, J., 1998: The evolution of locomotory mode in the lizard genus Niveoscincus. Unpubl. PhD thesis, School Zool., Univ. Tasm.: 186 pp.

Melville, J. \& Swain, R., 1997a: Spatial separation in two sympatric skinks, Niveoscincus microlepidotus and $N$ metallicus, from Tasmania. Herpetologica 53: 126-132.

Melville, J. \& Swain, R., 1997b: Daily and seasonal activity patterns in two species of high altitude skinks, Niveoscincus microlepidotus and $N$. metallicus, from Tasmania. J. Herpetol. 31: 29-37.

Melville, J. \& Swain, R., 1998: Evolutionary relationships within the snow skinks (Squamata: Scincidae: Niveoscincus) of Tasmania. Aust. Biol. 11: 22-25.

OlsSOn, M. \& ShINE, R., 1998a: Chemosensory mate recognition may facilitate prolonged mate guarding by male snow skinks, Niveoscincus microlepidotus. Behav. Ecol. Sociobiol. 43: 359-363.
Olsson, M. \& Shine, R., 1998b: Timing of parturition as a maternal care tactic in an alpine lizard. Evolution 52: 1861-1864

RAWLINSON, P.A., 1974: Biogeography and ecology of rhe reptiles of Tasmania and the Bass Strait area. In Williams, W. D. (Ed): BIOGEOGRAPHY AND ECOLOGY IN TASMANIA. W. Junk, The Hague: 291-338.

RAWLINSON, P.A., 1975: Two new lizard species from the genus Leiolopisma (Scincidae: Lygosominae) in sourheastern Australia and Tasmania. Mem. Natl Mus. Vict. 36: 1-16.

Rounsevell, D., Brothers, N. \& Holdoworth, M., 1985: The status and ecology of the Pedra Branca Skink Pseudemoia palfreymani. In Griggs G., Shine, R. \& Ehmann H. (Eds): BIOLOGY OF AUSTRALIAN FROGS AND REPTILES. Surrey Beatty \& Sons Pty Ltd, Chipping Norton, and R. Soc. NSW: 477-480.

ShIne, R., 1980: "Costs" of reproduction in reptiles. Oecologia 46: $92-100$

SWAIN, R. \& JONES, S., 1994: Annual cycle of plasma testosterone and other reproductive parameters in the Tasmanian skink, Niveoscincus metallicus. Herpetologica 50: $502-$ 509.

SWAin, R. AND JONES, S., 1997: Maternal-fetal transfer of 3Hlabelled leucine in the viviparous lizard Niveoscincus metallicus (Scincidae: Lygosominae). J. Exp. Zool. 277: $139-145$.

WAPSTRA, E. \& SWAin, R., 1996: The feeding ecology of the Tasmanian spotted skink Niveoscincus ocellatus. Aust.J. Zool. 44: 205-213.

WEBB, G.A., 1985: Habitat use and activity patterns in some southeastern Australian skinks. In Griggs G., Shine, R. \& Ehmann H. (Eds): BIOLOGY OF AUSTRALIAN FROGS AND REPTILES. Surrey Beatty \& Sons Pty Ltd, Chipping Norton, and R. Soc. NSW: 23-30.

WILSON, S.K. \& KNOWLES, D.G., 1988: AUSTRALIA'S REPTILES. Collins, Sydney.

(accepted 6 September 1999) 